Marquette University

e-Publications@Marquette

College of Education Faculty Research and

Publications

Education, College of

$11-1-2012$

Social Justice Begins at Home: The Challenges and Successes of a Social Justice Living-Learning Community

Jody Jessup-Anger

Marquette University, jody.jessup-anger@marquette.edu

Renee Piquette Dowdy

University of Chicago

MaryJanz

Marquette University

Published version. Journal of College \& Character, Vol. 13, No. 4, (November 2012). DOI. (C) 2012

Walter de Gruyter. Used with permission. 


\section{Social Justice Begins at Home: The Challenges and Successes of a Social Justice Living-Learning Community}

Jody E. Jessup-Anger, Marquette University

Renee Piquette Dowdy, University of Chicago

Mary Janz, Marquette University ${ }^{1}$

\section{Abstract}

This article describes the development of the Dorothy Day Social Justice Community, a sophomore, social justice-focused living-learning community at Marquette University. The authors describe the administration of the community, discuss various elements of the community, and share assessment results. They also detail lessons learned from three years of administering the community, namely that support should be built throughout the university, barriers removed to student participation, a voice given to students in the administration of the community, and assessment done to guide practice.

Living-learning communities (LLCs) are widely accepted as a high-impact practice, engaging students at "levels that elevate their performance across multiple engagement and outcome measures" (Kuh, 2008, p. 24). When thoughtfully designed, LLCs create seamless learning environments that cohere and reinvigorate undergraduates' educational experience. In these communities, students "(1) live together on-campus, (2) take part in a shared academic endeavor, (3) use resources in their residence environment designed specifically for them, and (4) have structured social activities . . . that stress academics" (Inkelas, Zeller, Murphy, \& Hummel, 2006, p. 11).

Researchers have found many academic (Inkelas \& Weisman, 2003) and involvement (Pike, 1999) gains for LLC students in comparison to their traditional residence hall peers. However, a more nuanced examination of LLCs revealed that these gains are largely dependent on the resources allocated to the community (Inkelas \& Soldner, 2011; Wawrzynski \& Jessup-Anger, 2010) and the elements included in the community, such as innovative pedagogy, coordinated coursework, or cocurricular activities (Inkelas, 2008). Because of the role context plays in the quality and outcomes of LLCs, it is important to consider the development and process aspects of these communities alongside their outcomes.

\footnotetext{
${ }^{1}$ Jody E. Jessup-Anger is assistant professor of higher education in the Department of Educational Policy and Leadership Studies at Marquette University. Her research explores the role of collegiate environments in promoting student learning and development. Renee Piquette Dowdy is an assistant director in the Office of Undergraduate Student Housing at the University of Chicago. She is committed to engaging academic discovery through the programs and services of the residential experience. Mary Janz is associate dean for residence life at Marquette University. She supervises mid-management and full-time residence life staff. She serves on the advisory board for the Social Justice Living Learning Community.
} 
Several "how to" manuals provide important considerations for practitioners as they implement LLCs (Levine Laufgraben, Shapiro, \& Associates, 2004), which may include such issues as recruitment and participation of faculty (Gabelnick, MacGregor, Matthews, \& Smith, 1990; Lenning \& Ebbers, 1999), community continuity (Gabelnick et al.; Lenning \& Ebbers), and bridging student and academic affairs (Gabelnick et al.; Jessup-Anger, Wawrzynski, \& Yao, 2011; Lenning \& Ebbers; O’Hara, 2001). Other difficulties administrators face when developing LLCs include finding an administrative home for a community (Gabelnick et al.) and maintaining facilities conducive to community building (O’Hara).

The current literature is helpful in illuminating how to plan an LLC, but it does not depict the process of implementation and is largely context and focus free. It misses details about how to build collaboration, conduct assessment, and use evidence-based improvement. In this essay we share the development of the Dorothy Day Social Justice Community, a sophomore, social justice-focused LLC at Marquette University. Named after Dorothy Day (who cofounded The Catholic Worker newspaper and is largely credited for starting the Catholic Worker nonviolence movement), the community created opportunities for students to connect and make a difference in the Milwaukee community. We discuss the elements of the community and how they work together, our assessment of the community and how it has informed our practice, and lessons learned from the first three years. Throughout the article we detail how the community has enabled students to develop a deeper understanding of social justice alongside interested peers.

\section{Elements of the Community}

As a Catholic, Jesuit University, Marquette values social justice education and service to the community. These values provided a foundation for building the Dorothy Day Social Justice Community (DDSJC), in which sophomore students live together, take courses together, and participate in service-learning and other activities. At its inception, DDSJC seemed like an ideal addition to existing communities on our campus: There were no LLC options available to sophomores, and the social justice focus served as a continuation to an established first-year inclusive leadership LLC. DDSJC is administered by an advisory board comprised of representatives from service learning, campus ministry, residence life, community service, and the Office of the Provost. Faculty from theology and philosophy and several students are also included on the board. The board evaluates the progress of the community and oversees publicity, program planning, and student issues that emerge.

Students participating in DDSJC come from a variety of majors. They take one course together each semester, both of which count toward their general education requirements. In understanding the needs of Marquette students, it was critical that the DDSJC course requirement not add to students' credit load, but rather count towards a requirement, as students often double major and have little room for electives. The DDSJC advisory board identified the departments of philosophy and theology as able to provide sections of courses exclusively for DDSJC students, and selected sections of Philosophy of Human Nature (fall) and Christian Discipleship (spring) as the courses students would take together. The learning objectives for these course sections were consistent with other sections, but the faculty incorporated service-learning in the coursework and infused a social justice lens in course assignments and discussions.

After three years of focus group and survey data, the advisory board opted to change the spring class to Philosophy of Ethics to ensure students would have the same faculty member both semesters, adding continuity to the classroom experience. Willingness to evaluate the student experience and make changes as necessary was vital to sustaining the community. 
As part of their DDSJC courses, students participate in service-learning at sites throughout Milwaukee for an entire academic year (e.g., an AIDs resource center, English as a Second Language tutoring center, and senior center). These agencies, which all serve adults, were deemed most appropriate given the subject matter and goals of the coursework into which they were integrated. With few exceptions, students' service-learning sites remained constant throughout the year. Participation in service-learning was conceptualized as a way for students to extend their classroom learning, providing an experience that would raise questions about the human condition and encourage students to apply theories of human nature and the role of Christian discipleship. Sites were arranged by the service learning staff (with student input) and were determined in consultation with the faculty members and DDSJC board.

In the residential environment, students live together on two floors (one for men and one for women), each of which has a resident assistant (RA). The RAs are selected specifically for the DDSJC community during the overall staff selection process. Emphasis is placed on selecting RAs who have lived in the community, participated in community service, or taken social justice-focused coursework. RAs make decisions about and evaluate the needs of the hall environment. They work with the full-time residence hall director (RHD) to determine goals for hall programs, retreats, and service events. The RHD assists the RAs in establishing a student leadership team for the community, which is responsible for a variety of service, advocacy, and social events for the community. The creation of a DDSJC leadership team connects the residents who desire the most involvement, encouraging them to play a larger role in the hall community.

The RHD, RAs, and leadership team coordinate events, including an annual retreat off-campus with faculty and service-learning staff, an urban immersion experience, a soup kitchen volunteer event with faculty, and social outings in the city of Milwaukee. One event many students found meaningful was a service outing where DDSJC participants spent a day alongside community members, police officers, and social workers completing several beautification projects in an urban neighborhood. Following the service portion, participants shared a meal and engaged in a community circle discussion about the impact of their efforts on the neighborhood. In student focus groups and hall satisfaction surveys, many students mentioned this event as an important part of their DDSJC experience, as the event encouraged participants to serve and share their stories, perspectives, and perceptions of community needs.

The annual retreat, which takes place on a weekend just after the start of the academic year, plays a large role in establishing the direction and culture of the community. During the retreat, students get to know each other and set expectations for one another, staff members, and themselves. Students create a community compact that lays out rules that will guide their interactions with one another. The compact is utilized when interpersonal and roommate disputes arise. In addition, participants work together through a series of exercises to construct their own definition of social justice. The understanding of what social justice includes (and does not) varies, so defining it as a group serves as a way to help students further develop their understanding of the concept. During DDSJC's inaugural year, no retreat was provided. Feedback from a focus group indicated having one would be helpful. Holding a retreat has been well worth the time and resources, as a dramatic shift was seen in residents' interactions with one another and attitude toward the floor community.

\section{Measuring the Experience}

At its best, assessment provides information to address accountability as well as improvement (Keeling, 2004). Holding true to the collaborative nature of every aspect of the DDSJC, members of the advisory 
board partnered with a faculty member in the College of Education to assess the community during its second year. Using quantitative and qualitative methods, the assessment sought to determine whether the community was meeting several criteria that make LLCs a high-impact practice, and in particular what students gained as a result of their participation. For the quantitative component, we developed a survey specific to DDSJC using the Residence Hall Environment Survey (Wawrzynski \& Jessup-Anger, 2010) as a guide. With input from administrators well versed in their areas of expertise, we added questions pertaining to service-learning and effective LLC practice. Below are key results of the quantitative assessment.

Descriptive survey results from the first year of the assessment (a census survey with a response rate of $91 \%$ conducted during the spring semester of the community's second year in existence) overwhelmingly showed that students reported feeling a sense of well-being in the community, with $85 \%$ of students indicating that the DDSJC provided an avenue for personal development and $83 \%$ indicating they built satisfying relationships with peers in the community. Their academic interactions with peers were enriching as well, with $88 \%$ reporting feeling comfortable in the DDSJC classes, $78 \%$ reporting intellectual growth from their participation in DDSJC, 59\% engaging in intellectual discussions outside of class with peers in the community, and $54 \%$ indicating that they studied together outside of class. Students made fewer connections between courses, as only $7 \%$ of students said that they often or very often connected material from the two designated DDSJC courses, and 9\% said that they often or very often discussed material from their philosophy course (fall) in their theology course (spring). These assessment results informed the advisory board's decision to change the spring course to Philosophy of Ethics for the 2012-2013 academic year. To promote integration throughout the year, the fall and spring course will be taught by the same faculty member.

The majority of students indicated that DDSJC was a venue for having serious conversations with diverse peers, including students of a different race or ethnicity (58\%) and students with differing religious beliefs, political perspectives, or personal values (63\%). Fewer students believed that the community encouraged contact among students from different economic, social, racial, or ethnic backgrounds (43\%).

On the whole, DDSJC students built meaningful relationships with the faculty, with $85 \%$ believing that the faculty were interested in helping them grow in more than just academic areas and were generally interested in teaching. Students also reported satisfaction with opportunities to meet and interact informally with DDSJC faculty (66\%). They also shared that their nonclassroom interactions with faculty in Dorothy Day had a positive influence on their personal (61\%) and intellectual growth (51\%). Perhaps more interesting, only $29 \%$ of students reported that since entering Dorothy Day they had closer relationships to faculty, which might be an indication that these students already had developed close relationships with faculty prior to entering DDSJC, and that the community enabled them to continue building close relationships with faculty. Regarding hall staff, students overwhelmingly believed that their RA cared about them (85\%) and was committed to the ideals of the community (85\%). The majority of students $(70 \%)$ believed that residence hall staff were dedicated to making the community successful.

Students' service-learning participation enriched their DDSJC experience: believing it caused them to grow as a person $(82 \%)$, reflect more deeply on social justice $(80 \%)$, and deepened their connection to people who are different $(80 \%)$. The majority of students also said that their service-learning experience helped them understand social justice in Milwaukee (75\%) and made them feel connected to the Milwaukee community (66\%). Fewer students indicated that their service-learning experience deepened course discussion $(58 \%)$ or that service-learning reflection sessions deepened their Dorothy Day experience (39\%). 
In summary, the quantitative assessment provided evidence that the community was doing what it intended to do, namely providing students the opportunity to connect and make a difference in the Milwaukee community while developing a deeper understanding of social justice. Furthermore, the assessment enabled the advisory board to target particular aspects of the community for improvement, including selecting courses that assist students in making the linkages between classes, and examining how to support students in having diverse interactions and experiences with their peers.

\section{Lessons Learned}

Several years have passed since the creation of DDSJC. As we reflect on the community's successes and challenges, several factors stand out as important.

\section{Build Support}

The presence of an advisory board comprised of individuals throughout the university has been vital to maintaining the community. Having multiple constituents at the table when discussing issues like course selection or placement of the community in a particular residence hall made for a more informed conversation, as each person brought a different perspective to the table and had different resources to share. Furthermore, including more people in the decision-making process has increased the sense of commitment to addressing organizational challenges within the community as they arise.

\section{Remove Barriers to Student Participation}

A tension evident in planning the DDSJC was a desire to have an academic focus in the community but not saddle students with extra courses that may dissuade them from participating. In negotiating this tension, we opted not to select courses that might have fit perfectly the social justice emphasis of the community, instead favoring courses that fit well and could also count for students' core requirements. The students attracted to the community are highly involved academically and socially; many double major and have few opportunities for elective credits. In removing the need for students to take electives to participate in the community, we attract students with a diversity of majors and honor the fact that our students have many other academic priorities.

\section{Ensure That Students Have a Voice in the Community}

DDSJC provides several opportunities for student involvement in the administration of the community. In fact, the idea for initiating the social justice community came from a student who had been involved in an LLC during her freshman year who wanted to continue her involvement. That student was actively engaged in the initial planning and advisory board of DDSJC. RAs also serve on the advisory board. In addition there is a DDSJC representative on the Residence Hall Governance Council. Students can also get involved with the leadership team. These involvement opportunities increase students' commitment and ensure the community is meeting their needs. 


\section{Conduct Meaningful Assessment}

We have conducted several types of assessment in DDSJC, including collecting survey data about students' experiences, inviting students to participate in focus groups to discuss their experiences, and conducting individual interviews with students to hear more about their peer interactions. We shared the results of these assessments with the advisory board, who used them in making decisions about the community. It was because of assessment that we decided to add a retreat to the beginning of the academic year and a spring semester urban emersion trip, which many of our students identified as a catalyst for deeper relationships with their peers. Furthermore, assessment data revealed that students wanted additional leadership opportunities and ways to serve the community as a community. Consequently, a team of students and administrators planned a day of service to a neighborhood adjacent to the university. Finally, through assessment we learned about students' difficulty relating concepts in their coursework. As a result of that feedback, coupled with an anticipated vacancy in instructors, we changed the second semester course to relate more closely to the first semester course and provided the opportunity for a single faculty member to teach both courses.

\section{Conclusion}

When thoughtfully designed, LLCs can provide an avenue for students to connect meaningfully to their peers, faculty, coursework, and community. These interactions can shape students' undergraduate experiences and provide a foundation for long-term community engagement. As we have learned through our experience with DDSJC, the collaboration, student input, and systematic assessment needed to build and maintain communities can be difficult to navigate. However, our assessment data reveal that the outcome is worth the effort, as students are better connected to one another, their faculty and coursework, and their communities. Furthermore, they have a home in which to live their values.

\section{References}

Gabelnick, F. MacGregor, J. Matthews, R. S., \& Smith, B. L. (1990). Learning communities: Creating connections among students, faculty, and disciplines. New Directions for Teaching and Learning, no. 41. San Francisco, CA: Jossey-Bass.

Inkelas, K. K. (Ed.). (2008). Living-learning programs theme issue [Special issue]. The Journal of College and University Student Housing, 35(1).

Inkelas, K. K., \& Soldner, M. (2011). Undergraduate living-learning programs and student outcomes. In J. C. Smart \& M. B. Paulsen (Eds.), Higher Education: Handbook of Theory \& Research, 26, 1-57.

Inkelas, K. K., \& Weisman, J. L. (2003). Different by design: An examination of student outcomes among participants in three types of living-learning programs. Journal of College Student Development, 44, 335-368.

Inkelas, K. K., Zeller, W. J., Murphy, R. K., \& Hummel, M. L. (2006, January/February). Learning moves home. About Campus, 10(6), 10-16.

Jessup-Anger, J. E., Wawrzynski, M. R., \& Yao, C. W. (2011). Enhancing undergraduate education: Examining faculty experiences during their first year in a residential college and exploring the implications for student affairs professionals. Journal of College and University Student Housing, 38, 56-68.

Keeling, R. P. (Ed.). (2004). Learning reconsidered: A campus-wide focus on the student experience. Washington, DC: National Association of Student Personnel Administrators-Student Affairs Administrators in Higher Education and American College Personnel Association.

Kuh, G. D. (2008). High-impact educational practices: What they are, who has access to them, and why they matter. Washington, DC: Association of American Colleges \& Universities.

doi:10.1515/jcc-2012-1936

http://journals.naspa.org/jcc/

(c) NASPA 2012

JCC 
Lenning, O. T., \& Ebbers, L. H. (1999). The powerful potential of learning communities: Improving education for the future. ASHE-ERIC Higher Education Reports, 26, 1-137.

Levine Laufgraben, J., Shapiro, N. S., \& Associates. (2004). Sustaining and improving learning communities. San Francisco, CA: Jossey-Bass.

O’Hara, R. J. (2001). How to build a residential college. Planning for Higher Education, 30(2), 52-57.

Pike, G. R. (1999). The effects of residential learning communities and traditional residential living arrangements on educational gains during the first year of college. Journal of College Student Development, 40, $269-284$.

Wawrzynski, M. R., \& Jessup-Anger, J. E. (2010). From expectations to experiences: Using a structural typology to understand first-year student outcomes in academically based living-learning environments. Journal of College Student Development, 51, 201-217. 